\title{
Considerations in the Measurement of Lipid Panel Tests
}

\author{
Hakan Ayyıldız,' () Mehmet Kalaycı,' ${ }^{1}$ Oğuzhan Koca²
}

'Department of Biochemistry, Elazig Fethi Sekin City Hospital, Elazig, Turkey

${ }^{2}$ Department of Biochemistry, Karabuk University Training and Research Hospital, Karabuk, Turkey

Please cite this article as "Ayyıldız H, Kalaycı M, Koca O. Considerations in the Measurement of Lipid Panel Tests. Med Bull Sisli Etfal Hosp 2019;53(2):199-200".

\section{Dear Editor,}

We read with great interest Kilic Coban's study entitled "Can TG/HDL Ratio be an Accurate Predictor in the Determination of the Risk of Cerebrovascular Events in Youngsters?". ${ }^{[1]}$ We congratulate the author for this study. In addition, we would like to note a few points about the studied parameters for readers and the author.

This study included 112 patients aged $16-45$ years and 110 patients aged $>45$ years in addition to a control group comprising 113 patients age 16-45 years range without a history of stroke. In the study, serum lipid levels [total cholesterol, low-density lipoprotein (LDL), high-density lipoprotein (HDL), triglyceride (TG)] were measured in all the patients, and it was stated that these measurements were performed using the standard laboratory method.

Nowadays, most laboratories measure total cholesterol and TG levels enzymatically, but measure HDL levels using one of the following methods: homogeneous, lipoprotein precipitation, electrophoresis, ultracentrifugation, and chromatography. ${ }^{[2]}$ There is no description of the method used in the study. Methodological information in studies is significant for facilitating the understanding of the methodbased interferences of the mentioned parameters. Moreover, there is no information about the instruments assayed and the reagents used. For instance, which method was used to determine LDL levels, Friedewald's formula (Total cholesterol -(TG/5)- HDL) or one of the direct assay meth- ods? ${ }^{[2,3]}$ Every assay instrument has its own characteristic parameter-based matrix effects. Therefore, it is essential to acknowledge the instrument and reagent brand/model in publishings. ${ }^{[4]}$ Moreover, the limits of measured parameters (limit of detection) should be known prior to the study to eliminate statistically unacceptable edge values; otherwise, it would be inevitable to see high standard deviation values like TG $186.10 \pm 176.14$ in the study. Inclusion of the abovementioned information in the paper may enhance reader comprehension and provide insights for further similar studies. In conclusion, getting in contact with laboratory specialists and discussing the characteristics/interferences/instrument-based assay dynamics of measured parameters would minimize errors or prevent ambiguity.

\section{Disclosures}

Conflict of Interest: None declared.

Authorship Contributions: Concept - H.A., M.K., O.K.; Design H.A., M.K., O.K.; Supervision - H.A., M.K.; Materials - H.A., M.K., O.K.; Data collection \&/or processing - H.A.; Analysis and/or interpretation - H.A., M.K., O.K.; Literature search - H.A., M.K., O.K.; Writing - H.A.; Critical review - H.A., M.K., O.K.

\section{References}

1. Kılıc Coban E. Can TG/HDL Ratio be an Accurate Predictor in the Determination of the Risk of Cerebrovascular Events in Youngsters? Med Bull Sisli Etfal Hosp 2018;52:199-203.

2. Wu AHB. Tietz Clinical Guide to Laboratory Tests. 4th ed. Missouri:

Address for correspondence: Hakan Ayyıldız, MD. Elazig Fethi Seckin Sehir Hastanesi, Biyokimya Anabilim Dali, Elazig, Turkey Phone: +90 5057791672 E-mail: hknayyildiz@hotmail.com

Submitted Date: January 31, 2019 Accepted Date: Jun 26, 2019 Available Online Date: July 04, 2019 ${ }^{\circ}$ Copyright 2019 by The Medical Bulletin of Sisli Etfal Hospital - Available online at www.sislietfaltip.org OPEN ACCESS This is an open access article under the CC BY-NC license (http://creativecommons.org/licenses/by-nc/4.0/). 
Elsevier Saunders; 2006.

3. Friedewald WT, Levy RI, Fredrickson DS. Estimation of the concentration of low-density lipoprotein cholesterol in plasma, without use of the preparative ultracentrifuge. Clin Chem 1972;18:499-502.

4. Panuwet P, Hunter RE Jr, D'Souza PE, Chen X, Radford SA, Cohen $J R$, et al. Biological Matrix Effects in Quantitative Tandem Mass Spectrometry-Based Analytical Methods: Advancing Biomonitoring. Crit Rev Anal Chem 2016;46:93-105. [CrossRef]

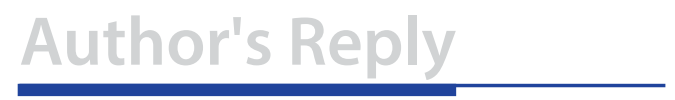

Dear Editor,

I thank the researcher for her/his interest in our article entitled "Can TG/HDL Ratio be an Accurate Predictor in the Determination of the Risk of Cerebrovascular Events in
Youngsters?" that was published in the March 2018 issue of the Medical Bulletin of the Sisli Etfal Hospital. Lipid measurement devices available in our institute were used. This study aimed to determine whether or not it is possible to evaluate the risk of ischemic cerebrovascular disease using a calculable method without any additional cost or great effort. Beckman Coulter AU680 and AU480 analyzers were used. LDL levels were calculated using the Friedewald formula. Total cholesterol, $\mathrm{HDL}$, and triglyceride levels were measured using the enzymatic colorimetric method.

Sincerely,

(D) Eda Kılıç Çoban

Department of Neurology, Bakırköy Mental and Neurological Diseases Training and Research Hospital, Istanbul, Turkey

E-mail: eda_coban@yahoo.com

Doi: 10.14744/SEMB.2019.87513 